\title{
Strategy Of Department Of Culture And Tourism In TTU Regency To Develop Tanjung Bastian Beach As An International Destination
}

\author{
Egidius Fkun $^{1}$, Fidelis Atanus ${ }^{2}$ \\ \{fkunegy@yahoo.co.id, atanusf@gmail.com\}
}

Ilmu Pemerintahan, Universitas Timor ${ }^{1}$, Ilmu Administrasi Negara, Universitas Timor ${ }^{2}$

\begin{abstract}
The method used in this research is qualitative with a focus related to the development of amenities, accessibility and attractions. The results of the research show that the strategy of the government related to the amenities have not been managed until now because the tourism sector is not a regional flagship program and this has an impact on the budget. In accessibility aspect was found that the lack of access of transportation that still not support tourism in Tanjung Bastian. In attractions aspect was found that it had been carried out with routine activities namely horse racing involving the neighboring country namely the Democratic Republic of East Timor.
\end{abstract}

Keywords: Amenities, Accesibility, Attractions

\section{Introduction}

Tanjung Bastian is one of the attractions in the district of North Central Timor (TTU), East Nusa Tenggara (NTT). The name of Tanjung Bastian is not familiar as Kuta beach, Bali, but the natural charm of Tanjung Bastian beach is no less good, aka having amazing natural beauty. Tanjung Bastian is located in the northern part of the TTU district, precisely in Wini, with a distance of $65 \mathrm{~km}$ from Kefamenanu City (the district capital). The location of Tanjung Bastian beach is very strategic because it is easily accessible either by bus, travel or even using the services of a motorcycle taxi driver. Tanjung Bastian beach is famous for its white sand that reaches tens and even hundreds of meters, the water is clear, the local people are friendly and polite making Tanjung Bastian as a safe place for anyone who comes here (Tanjung Bastian). Besides being used as a tourist attraction [4], Tanjung Bastian also become a place or arena to hold sporting events such as horse racing. The horse racing track at Tanjung Bastian is the most beautiful race track in Indonesia. Therefore, it is necessary to optimize the development of the Tanjung Bastian tourist area.

Based on the RPJMD of TTU Regency in 2017-2021, stated that the tourism sector is one of the leading sectors. This is contained in the first mission that is: Empowering local economy based on superior potential of the environmentally oriented and synergistically sustainable environment [3]. In the regional development agenda, especially on point d, it is stated that Tourism matter emphasized on the Tourism Destination Development Program, Tourism Promotion Development Program, and Partnership Development Program. This is in line with the Strategic Plan of the Department of Culture and Tourism in the TTU Regency as outlined in its vision, that is: Becoming a Cultural-Based Border Tourism Destination Region towards an independent prosperous community [3]. This vision was later elaborated in one of its mission, that is developing superior tourism destinations and industries. It is also operationally stated in the goal of developing a competitive, credible tourism industry, driving business partnerships and being responsible for the natural and socio-cultural environment. 
To achieve this vision, mission and goals, department of culture and tourism in TTU regency established a strategy and policy direction for tourism marketing development, through: developing the tourist market, developing the tourism image, developing tourism marketing partnership and developing tourism promotion. This is intended to strengthen tourism in the TTU Regency.

However, based on the observations and assumptions of the researchers, several important problems were found including:

a) The low number of tourist arrivall, both domestic and foreign. In 2016 the number of visits was 9.679 people, in 2017 the number of visits was 8.669 (TTU in 2017 figures).

b) The tourism objects are not well organized.

c) The unavailability of highly competitive tourism objects.

d) Some tourism objects are in the forest area.

e) The lack of basic infrastructure and supporting public facilities is inadequate. In Tanjung Bastian clean water facilities are inadequate, swimming pool facilities are in a heavily damaged condition, and business outlets are not yet available to meet the needs of visitors, such as culinary and souvenirs.

f) The low quality of tourism human resources including business skills, service attitude to customers, less communicative, less neat appearance and so forth.

g) Cooperation in the field of tourism is still very minimal.

Although the TTU district government through the Department of Culture and Tourism has tried to overcome this problmes, but to date the basic facilities and supporting tourism in Tanjung Bastian has yet to be repaired or noticed. In addition, there are also no supporting tourism facilities such as hotels, restaurants that are standard and adequate in serving travelers.

Based on these descriptions, the researchers conducted a study with the title "Strategy of Department of Culture and Tourism in TTU Regency to Develop Tanjung Bastian Beach as an International Destination." The problems in this research is: What is the Strategy of Department of Culture and Tourism to develop Tanjung Bastian beach as an international destination. The purpose of this study is to describe and analyze the Strategy of Department of Culture and Tourism to develop Tanjung Bastian beach as an international destination.

To better help understanding the strategy of Department of cultural and tourism ini TTU Regency to developing Tanjung Bastian beach as an international destination, some theoreticl grounding is needed. Researchers use some of the following theoretical studies.

1. Strategy Concept

The word strategy comes from the word strategyos in Greek is a combination of stratos (soldiers) and egos (leaders). A strategy has a basis or a intended scheme. So basically the strategy is a tool to achieve the goal. According to Kusdi [6] understanding of strategy in the context of the organization is the determination of various long-term goals and objectives that are fundamental to an organization, followed by the determination of activity plans and the allocation of resources needed to achieve these targets. Johnson and Kevan (2005: 141) in his book "Exploring Corporate Strategy", defines strategy as the long-term direction and scope of the organization to gain excellence through the configuration of resources in a changing environment to meet market needs and meet the expectations of stakeholders [5].

2. Types of Strategies

Basically every organization has a strategy to achieve organizational goals that have been set. The types of strategies used in each organization are not the same. There are several types of strategies used in an organization in achieving its stated goals. Jack Koteen (1997: 343) in [13] revealed that in the strategy there are several types of strategies [6], including: 1) Corporate 
Strategy, which is related to the formulation of mission, goals, values and initiatives new strategy. 2) Program Strategy, which pays more attention to the strategic implications of a particular program. Approximately what is the impact if a particular program is launched or introduced. 3) Resource Support Strategy that focuses on optimally utilizing essential resources that are available to improve the quality of organizational performance. 4) Institutional Strategy, which is more focused on developing organizational capacity to carry out strategic initiatives [7].

3. Strategic Management Concepts

Strategic management is a process or series of activities implemented by all levels within an organization, to achieve its objectives. According [9], strategic management is large-scale planning (called strategic planning) oriented to the reach of a distant future (called vision), and determined as the decision of the highest leader (called mission), in an effort to produce something (operational planning to produce quality goods and / or services), aimed at optimizing the achievement of goals (called strategic goals) and the various goals (operational objectives) of the organization.

Barney, 1997: 27 mentions, strategic management can be understood as the process of selecting and implementing strategies. Whereas strategy is a pattern of resource allocation that enables organizations to maintain performance [15].

4. Tourism

Tourism comes from two words in Indonesia language that is, Pari and Wisata. Pari can be interpreted as many, many times, circling or complete. While wisata can be interpreted as a trip or traveling, in this case synonymous with the word "travel." On that basis, the word "tourism" can be interpreted as a trip that is made many times or circling from one place to another, or which is called "Tour" [17].

According to James J. Spillane (1982: 20) tourism is an activity of traveling with the aim of getting pleasure, seeking satisfaction, knowing something, improving health, enjoying sports or resting, fulfilling tasks, making pilgrimages and others [8]. A.J. Burkart and S. Medik (1987) suggest that tourism is the temporary and short-term movement of people to destinations outside the place where they usually live and work and their activities while staying at these destinations [11].

\section{Research Methods}

The type of research used in this research is descriptive. This method discusses several possibilities for solving existing problems by collecting, compiling, classifying, and interpreting data and finally concluding. This descriptive research is intended to give an overview of the Strategy of the Office of Culture and Tourism in Developing Tanjung Bastian Beach Tourism Objects as an International Destination.

The purpose of descriptive research is to make a systematic, factual and accurate description of the phenomenon, or the relationship between the phenomena studied without special treatment [14]. It is hoped that the use of these methods can provide a factual description of the Culture and Tourism Service Strategy in Developing Tanjung Bastian Beach Tourism Objects as an International Destination.

In the context of the focus of the research to be studied, the main focus of this research is: Strategy of the Office of Culture and Tourism in Developing Tanjung Bastian Beach Tourism Objects as an International destination with sub-focus to amenities, accesibility and attractons. In this study, the types and sources of data that will be used are:

1. Informant 
Informants are people who are knowledgeable and are directly involved in the research problem. The informant who acts as a source of data is seen from the capacity and strategic position of the TTU District Culture and Tourism Office.

2. Document

The documents used in this study are official documents issued by the government in the form of laws, PPs, Standing Orders, Decrees, as well as Manteri's decisions or documents, records, reports.

3. Literature review

Sourced from the results of reading literature or books or data related to the research topic. Plus online data browsing, with data search through internet facilities.

The techniques to be taken in data collection are as follows: observation, interview and documentation.

The data analysis technique used in this study is qualitative analysis which is a method or method used by researchers to describe social phenomena that occur in society. The data analysis model in this study uses the Milles and Haberman's data analysis model as quoted by [15] as follows data reduction, data display and drawing/verification conclusions.

\section{Research result And Discusion Amenitas}

Amenitas is a supporting facility for the smooth runnng of tourism activities which is also intended to provide comfort to tourist. Amenitas become one of the requirements of the tourist destination so that tourists can feel at home staying longer in one of the attractions. Usually the accommodation desired by tourists who visit is a means of communication, health centers, souvenir centers, hotels and restaurants that are easy to reach, and can fulfill what tourists want while in the attractions they visit [4].

Observations and interviews related to the strategy of the Department of Culture and Tourism in developing Tanjung Bastian Tourism objects from the aspect of amenities iundicated that the accommodation desired by tourists has not been fulfilled. The Department of Culture and Tourism has established a strategy outlined in the Tourism Development Master Plan for TTU Regency, but this has not been maximally implemented because the allocation of funds related to tourism development is still in certain processes and priorities. This was stated by an employee of the Department of Culture and Tourism with the initials JA that:

"Tanjung Bastian Tourism Object until now has not been well taken care of. This is because it is still in process and there are certain priorities [7]. We have formulated a strategy related to tourism development specifically relating to the accommodation through the Master Plan Development of tourism in TTU Regency, which was ratified in 2017 with a period of up to 2025. Namely in first section on the development of Regency Tourism Destination (RTD) point 1.4 concerning development of public infrastructure, Public Facilities, and Tourism Facilities. With this RIP there may be a significant allocation of funds to create a comfortable atmosphere for visitors [1].

The same thing was also conveyed by one of the heads of division in Departments of Culture and Tourism the initials AB that:

"We have tried to develop our tourism through developing partnerships with other parties in tourism management to provide hotels and food that make local and foreign tourists stay longer in Tanjung Bastian, but still constrained by finance. Regarding the development of tourism business partnerships, it has been outlined in our RIP, especially in point 2.3 with a strategy, 
namely: strengthening cooperation between local governments, the private sector, and the community [4].

The researcher then asked the leader about the target of developing tourism, especially Tanjung Bastian Tourism objects. He mentioned that:

"Our goal is the creation of integrated tourism between the border and the surrounding tourism area and the development of coastal tourism, to support the protection of coastal ecosystems and culture. The target market for tourists is domestic and foreign tourists, especially those from Timor Leste. For this reason, it is necessary to have tourism facilities such as providing rest areas, providing clean water facilities, providing sanitation facilities, providing health facilities for emergency response, providing public toilets and providing marine facilities. These are our programs and strategies in developing Tanjung Bastian tourism objects [3].

Based on the results of the interview, it can be concluded that the Tanjung Bastian tourism object has yet to be taken care of, because it is still in the budgeting process and there are certain priorities. The development strategy has been carried out by creating a Tourism Development Master Plan TTU Regency [3].

\section{Accessibility}

Accessibility is a facility that makes it easy for tourists to reach tourist destinations. Accessibility is intended so that domestic and foreign tourists can easily reach tourist attractions. Access to tourism in Indonesia is quite good but there are still some that are not good and do not support access to Indonesian tourism. Important factors in accessibility include: travel plans, tourist attraction data, airports, land transportation, time needed to get to tourist attractions, costs for transportation, and the number of vehicles to travel [4].

Based on observations and interviews found that, the access that has been supporting in tourism in Tanjung Bastian is access to transportation. Most visitors use transportation that is rented from Kefamemanu City or using private vehicles. Regarding the strategy of the Department of Culture and Tourism of TTU in developing Tanjung Bastian Beach Tourism Objects, it has been stated in the RIP, which is point 3 about Tourism Acceleration Development, as revealed by an official of the Department of Culture and Tourism with the initials LK that :

"Transportation access to Tanjung Bastian Beach Tourism Object has been effective for public transportation services to these locations. Indeed, we have tried through a plan to add a public fleet to Tanjung Bastian through the RIP, in point $1 \mathrm{C}$ that is: increase the transportation capacity and transportation capacity in RDP.

The same thing was also conveyed by one of the heads of the initials GF that:

"We have done our strategy to develop tourism objects in the preparation of the budget but we have collided with the priorities of the regional government. But there is hope with the current governor of NTT with its flagship tourism program there can be hope for how to develop Tanjung Bastian tourism objects.

The researcher then asked the Chairperson about the transportation problem stated that:

"There has been a strategy through the TTU Tourism RIP that has been approved where there is one of our priorities, namely the tourism car prepared by the Government to serve domestic and foreign tourists with a cohesive and tour strategy and this will be temporarily in the coming years.

Based on the results of the interview above, it can be concluded that access that is sufficient to support tourism in Tanjung Bastian is access to transportation. Most visitors use transportation that is rented from Kefamemanu City or using private vehicles. The strategy of 
the Department of Culture and Tourism of TTU in developing Tanjung Bastian Beach Tourism Objects, it has been stated in the Development Master Plan.

\section{Attractions}

Attractions are the allure of a tourist attraction or the results of the arts of an area that attracts tourists to visit these tourist attractions. Each tourist destination must have an attraction, both natural and community attraction and its culture to attract tourists. All the creations of God Almighty, in the form of natural conditions and flora and fauna, such as: natural scenery, beautiful panorama, jungle with tropical forest plants, and rare animals. In addition, human works in the form of museums, ancient relics, historical relics, cultural arts, agro (agricultural) tourism, tirta (water) tourism, adventure tourism, recreational parks, and entertainment venues are allures to attract tourists [4].

The results of interviews with regard to the strategy of Department of Culture and Tourism relating to attractions mentioned that the aspect of attractions that are done every year is horse racing. This was stated by one of the heads of sub-sections with the initials GF that:

" Every year we always organize horse racing events with the Border cross theme to attract foreign tourists [3]. With this activity, it is expected that people can enjoy the view of Tanjung Bastian and have the desire to return to Tanjung. This activity was enough to attract the attention of the community of tourism lovers both domestic and foreign tourists.

The same thing was also conveyed by the head of the Tanjung Bastian KTU with the initials OL that:

"It is true that every year horse racing events are held here. At that time many visitors and exploded. We hope that not only horse racing events but other events such as cultural festivals or similar activities so that Tanjung Bastian is always crowded and can be considered more seriously. Indeed, here facilities and infrastructure are still very minimal. There are no basic facilities such as clean water and a place to rest, there is already a swimming pool but until now it is damaged and has not been repaired. It is expected that there is a good and appropriate strategy in handling this Tanjung Bastian.

Regarding the strategy of the Department of Culture and Tourism of the TTU Regency in conducting attractions to attract domestic and foreign tourists, the researchers asked the leaders to say that:

"All the strategies have been included in the RIP and just have to be executed. In connection with the attrition, we have made in the Master plan for development, which in section 3.2 about the development of tourism images through polices to increase promotion and tourism image through local and cultural attractions.

Based on the results of the interview, it can be concluded that the strategy of Department of Culture and Tourism to developing Tanjung Bastian beach tourism objects through attractions has been going quite well through routine activities that is horse racing, involving the Neighboring Countries namely RDTL. This has a positive effect where visitors are booming. However, it is recommended that activities other than horse racing also need to be carried out at Tanjung Bastian routinely, such as cultural performances or other public entertainment activities. In connection with the strategy, it is stated that all policies and strategies are contained in the Tourism Development Master Plan of TTU Regency and are ready to be implemented.

\section{Discussion}


The results of research about Strategy of Department of Cultural and Tourism relating to the aspect of amenities found that, the Tanjung Bastian tourism object has not yet been taken care of, because it is still in the budgeting process and there are certain priorities in development. The tourism development strategy has been carried out by creating a Tourism Development Master Plan of TTU regency [3]. In the RIP several policies relating to amenities have been formulated, namely by providing accommodation and comfort for domestic and foreign tourists. In addition, there are also plans to create integrated tourism between the border and the surrounding tourism area and the development of coastal tourism to support the protection of coastal ecosystems and culture, with the target market for tourists being domestic and foreign tourists, especially those from Timor Leste. Efforts to provide tourism facilities in the form of providing rest areas, providing clean water facilities, providing sanitation facilities, providing health facilities for emergency response, providing public toilets and providing marine facilities are included in the planning.

Related to accessibility aspects, based on the results of research on the strategy of the Department of Culture and Tourism of TTU Regency, it was found that sufficient access to support in tourism in Tanjung Bastian is transportation access where tourists often use rental cars or private vehicles. This happens because in general, the transportation fleet is still lacking [3]. Regarding the strategy of the Department of Culture and Tourism of TTU Regency in developing Tanjung Bastian Beach Tourism Objects, it has been stated in the Development Master Plan

While related to the aspect of attraction, based on research on the strategy of the Department of culture and tourism in developing Tanjung Bastian beach tourism objects through attractions it was found that it has been done with routine activities namely horse racing involving the Neighboring country namely RDTL. This has a positive effect where visitors are booming. However, it is suggested that activities other than horse racing also need to be carried out at Tanjung Bastian routinely such as cultural performances or other people's entertainment activities. Regarding the strategy, it is stated that all policies and strategies are contained in Tourism Development Master Plan and are ready to be implemented

\section{Conclusion}

1. The strategy of Department of Culture and Tourism related to amenity found that Tanjung Bastian tourism object has not been taken care of up to now because it is still in the budgeting process and there are certain development priorities. The development strategy has been carried out by creating a Tourism Development Master Plan for TTU regency. In this RIP, several policies relating to Amenities have been formulated, namely by providing accommodation and comfort for domestic and foreign tourists.

2. In accesibility aspect, is found that sufficient access to support in tourism in Tanjung Bastian. Most visitors use transportation that is rented from Kefamemanu City or using private vehicles. The strategy of the Department of Culture and Tourism of TTU in developing Tanjung Bastian Beach Tourism Objects, it has been stated in the Development Master Plan.

3. In a attractions aspects, is found that it has been carried out with routine activities namely horse racing involving the neighboring country namely RDTL. This has a positive effect where visitors are booming. Regarding the strategy, it is stated that all policies and strategies are contained in the TTU District Tourism Development Master Plan and are ready to be implemented.

\section{Suggestion}


Based on the results of the research and discussion of the theory above, the researcher can suggest several things including:

1. The Department of Culture and Tourism of TTU Regency needs to improve the existing basic facilities in Tanjung Bastian.

2. The Department of Culture and Tourism of TTU Regency needs to go through a budget political strategy to increase the budget in improving public facilities such as toilets and swimming pools in Tanjung Bastian.

3. The need for cooperation between agencies and agencies in managing Tanjung Bastian, especially related to attractions.

4. The need to increase the HR management of coastal tourism objects, especially Tanjung Bastian.

5. The Department of Culture and Tourism of TTU Regency needs to work closely with the private sector in managing Tanjung Bastian.

\section{References}

[1] Arthur.A., Strickland, AJ: Strategic Management, Ninth Edition, Van Hoffman Press, Inc. (1996)

[2] Certo, Samuel C. \& J. Paul Peter: Strategic Manajement: Concepts And Applications. Chicago: Austen Press (1994)

[3] Departement of Culture and Tourism of TTU Regency : Tourism Development Master Plan TTU. TTU-Kefamenanu (2017)

[4] Damardjati, R.S : Istilah-istilah Dunia Pariwisata. Jakarta: Pradya Paramita (2006)

[5] David, Fred.R : Strategic Management, Seventh Edition. New Jersey: Prentice Hall International, Inc. (1999)

[6] Kusmayadi, Endar S : Metodologi Penelitian dalam Bidang Kepariwisataan. Jakarta:

PT Gramedia Pustaka Utama. (2000)

[7] Marpaung, Happy : Pengetahuan Kepariwisatan. Bandung: Alfabeta Bandung (2002)

[8] Musanef : Manajemen Pariwisata di Indonesia. Jakarta: PT. Toko Gunung Agung (2003)

[9] Nawawi, Hadari : Manajemen Stratejik. Yogyakarta: Gadjah Mada Press Yogyakarta (2003)

[10] Pendit, Nyoman. S : Ilmu Pariwisata Sebuah Pengantar. Jakarta: Pradya Paramita. (2002)

[11] Rabin et al : Handbook Of Strategic Management. New York: Marcell Dekker (2000)

[12] Samsuridjal D and Kaelany HD : Peluang di Bidang Pariwsata. Yogyakarta:

Mutiara Sumber Widya (1997)

[13] Salusu, J : Pengambilan Keputusan Strategik Untuk Organisasi Publik dan Organisasi Non Profit. Jakarta: Rasindo (2003)

[14] Siagian, P. Sondang : Manajemen Stratejik. Jakarta: Bumi Aksara (2004)

[15] Suwantoro, Gamal : Dasar-daar Pariwisata. Yogyakarta: Andi Publisher (2004)

[16] TTU District : RPJMD 2017-2021. Kefamenanu (2017)

[17] Yoeti, Oka. A : Pengantar Ilmu Pariwisata. Bandung: Angkasa (2009) 